\title{
Neurological assessment and education of learners with specific learning disabilities in Nigeria
}

\author{
James Bassey Ejue, Orim Samuel Orim
}

\begin{abstract}
This study investigated the relationship between neurological assessment and education of learners with specific learning disabilities with particular focus on placement options and the design of instructional programme. Survey design and quantitative approach was used, 180 professionals in specific learning disabilities were purposively sampled from tertiary institutions and special education centers in Nigeria. A 21 item questionnaire with reliability coefficient of 78.6 was used as instrument for data collection and method for data analysis was Pearson product correlation. The result of the findings indicates that there is a strong positive correlation between the variables investigated and measured. Based on the result of the study it was recommended among others that, parents should be educated on relevance of neurological assessment of the children, particular attention should be given to neurological assessment of learners with specific learning disabilities as a parameter for quality education, professionals in the field should partner with Neuropsychologist to provide services in line with global best practices, template and code of conduct should be developed to guide the process in Nigeria.
\end{abstract}

Key words: Neurology, assessment, placement, instruction, learning disabilities. 


\title{
Neurologické hodnocení a vzdělávání osob se specifickými poruchami učení v Nigerii
}

\begin{abstract}
Abstrakt
Tato studie zkoumala vztah mezi neurologickým hodnocením a výukou žáků se specifickými poruchami učení se zaměřením na možnosti umístění a navrhování vzdělávacích programů. Pro výzkum bylo použito průzkumu a kvantitativního přístupu, 180 odborníků z oblasti specifických poruch učení bylo účelově vybráno z terciárních institucí a speciálních vzdělávacích center v Nigérii. Jako nástroj pro sběr dat byl použit dotazník s 21 položkami s koeficientem spolehlivosti 78,6 a metodou pro analýzu dat byl použit Pearsonův korelační koeficient. Výsledek zjištění naznačuje, že mezi zkoumanými a měřenými proměnnými existuje silná pozitivní korelace. Na základě výsledku studie bylo mimo jiné doporučeno, aby rodiče byli informováni o významu neurologického hodnocení dětí; zvláštní pozornost by měla být věnována neurologickému hodnocení studentů se specifickými poruchami učení jako parametru pro kvalitní vzdělávání; odborníci v oboru by měli spolupracovat s neuropsychology a poskytovat služby v souladu s celosvětovou osvědčenou praxí; a šablony a kodexy chování by měly být vypracovány tak, aby vedly tento proces v Nigérii.
\end{abstract}

Klíčová slova: neurologie, hodnocení, umístění, výuka, poruchy učení.

\section{Introduction}

Sustainable Development Goal (SDG) 4 and other global policy framework in line with the Nigerian National policy on education adjudged education as a universal potent tool for individuals including those with specific learning disabilities and societal development. Educating this category of learners is seemingly prescriptive or clinical as it relies heavily on assessment which determines other instructional variables critical to the success of the process. The uniqueness of specific learning disabilities as a category of exceptionality with the highest prevalence in the school and society requires assessment beyond the general norm in special needs education practice. This is arguably true because it implicates the state of the brain and the central nervous system more than other disabilities. This is why National Joint Committee on Learning Disabilities (NJCLD) traced the etiology to dysfunction of central nervous system. Association of Learning Disabilities of Canada (ALDC) and the neurology school of thought and theorists equally associate this disability with deficits in the ability of the brain and central nervous system to process information through the input and output mechanism. Researches such as Hinshelwood in Lerner (1997), Goldstein in Pierangelo and Giuliani (2006)), Werner 
and Strauss (1940), Wong (2004) and Barbara and Cote (2012) indicate that dysfunction of the brain functions is majorly one of the causes of specific learning disabilities.

Base on the foregoing, it is obvious that assessing the functionality of central nervous system of learners with specific learning disabilities is cardinal to quality of their education. Orim (2018), asserts that providing quality pedagogical intervention for children with learning disabilities begins with general assessment and progress to more specific assessment called neurological diagnosis also known as neurological assessment. Neurological assessment in simple terms is a process of gathering verifiable information from relevant and reliable sources about the functionality or otherwise of central nervous system (CNS) primarily to enhance planning, placement, designing, implementing and perhaps evaluation of pedagogical intervention for learners with specific learning disabilities. Neurological assessment provides information on hemispheric specialization where it exists for diagnosis and interventional plans. In the foundational phase or brain research stage of the development of learning disabilities this form of assessment was done through postmortem Anatomical studies/ autopsy. With advances in science and technology there is a marked improvement as neuro-imaging techniques such as, the Computed Tomography Scan (STS), Magnetic Resonance Imaging (MRI), Functional Neuro-imaging Techniques (FNT), Brain Electrical Activity Mapping (BEAM) among others are commonly used for diagnosis (Pierangel \& Giuliani, 2006). Despite the relevance of this assessment it is quite unfortunate that in Nigeria, education or instruction for learners with this disability is designed without regards to research proven relationship between assessment and teaching. This implies that the deficits in the learner's CNS that would have served as input into the educational programme is neglected consequently making instruction not prescriptive or clinical.

Neurological assessment requires collaboration with different professionals such as neuropsychologist, Educational psychologist, Pediatricians, Speech pathologists and special educationist with specialization in specific learning disabilities. Like other assessment practice, neurological diagnosis takes in consideration the following principles; comprehensive, confidential, accessible to authorized persons, participatory and dynamic.

\section{Research hypotheses}

The study is guided by two research hypotheses, framed thus:

1. There is no significant relationship between neurological assessment and placement options for learners with specific learning disabilities.

2. There is no significant relationship between neurological assessment and the design of instruction for learners with specific learning disabilities 


\section{Statement of problem}

Specific learning disabilities as neurobiological or cognitive disabilities interfere with normal functions of the central nervous system as main engine room of any learning activity. It presents serious difficulties in acquiring and processing information despite normal intellectual ability of the child. This specifically impairs basic academic skills of reading, writing, speaking, ability to perform calculation, and reasoning needed for success in school and the society. This poses problems of what appropriate educational placement and the nature of instruction to be designed for the child. Professionals including the researchers have noticed that despite efforts of teachers, parents and other stakeholders in education of learners with specific learning disabilities much is yet to be desired in terms of quality education and learning outcome, even when many of the clients go through diagnostic and ecological assessment of the disability. Research indicates that children with this disability are merely enrolled in school without intervention assessment such as neurological assessment to determine the functionality of their central nervous system as one of the conditions for appropriate education of this category of learners. Teachers and parents are worried about this unprofessional practice that focuses only on a part of assessment practice. The border line problem of this study is poor quality of education and learning outcome has been associated with children with specific learning disabilities in spite of stakeholders' efforts. This study is therefore designed to find out:

- If there is any relationship between neurological assessment and education of learners with specific learning disabilities.

- If there is any relationship between neurological assessment and educational placement options for children with the disability.

- If there is any relationship between neurological assessment and instructional design for this group of learners.

\section{Methodology}

The study adopted quantitative research and survey design, 180 participants who are professionals in the field of specific learning disabilities were purposively sampled from a population of 180 lecturers in five tertiary institutions that run the programme in Nigeria. An instrument tilted Questionnaire on Neurological Assessment of Specific Learning Disabilities (QNASLD) with five response scale was developed by the researchers and validated by experts in relevant areas. Split-half reliability method was used to estimate its reliability which ranged from 69.8-78.6 and it was considered good enough to use for data collection. The instrument was sent to 200 participants through their emails 
and 180 were return, Pearson product moment correlation was used as method of data analysis with the help of SPSS software.

\section{Presentation of result}

Hypothesis 1:There is no significant relationship between neurological assessment and placement options for learners with specific learning disabilities.

Table 1

Pearson Product Moment Correlation Analysis of the Relationship between neurological assessment and placement options for learners with specific learning disabilities $(N=180)$

\begin{tabular}{|l|c|c|c|c|c|c|}
\hline Variables & Mean & SD & $\sum x^{2} \sum y^{2}$ & $\sum x y$ & Sig & $R$ \\
\hline Neurological assessment & 51.88 & 17.56 & 1360.13 & & & \\
\hline Placement options for learners with specific learning disabilities & 55.71 & 19.07 & 1432.31 & 1531.33 & .004 & 0.63 \\
\hline
\end{tabular}

$P<0.05, d f=178$

The Table 1, shows that neurological assessment with a mean of 51.88 and SD of 17.56 and placement options for learners with specific learning disabilities with mean of 55.71 and SD of 19.07 and sig. of 0.004 produced a coefficient $r=0.63$ at degree of freedom of 178 indicates that neurological assessment is significantly related to placement options for learners with specific learning disabilities. Therefore, the null hypothesis was rejected. This indicates that neurological assessment offers very important source of information in the educational placement of learners with specific learning disabilities.

Hypothesis 2: There is no significant relationship between neurological assessment and the design of instruction for learners with specific learning disabilities.

Table 2

Pearson Product Moment Correlation Analysis of the Relationship between neurological assessment and the design of instruction for learners with specific learning disabilities $(N=180)$

\begin{tabular}{|l|c|c|c|c|c|c|}
\hline Variables & Mean & SD & $\Sigma x^{2} \Sigma y^{2}$ & $\Sigma x y$ & Sig & $R$ \\
\hline Neurological assessment & 51.88 & 17.56 & 1360.13 & & & \\
\hline Design of instruction for learners with specific learning disabilities & 57.71 & 19.97 & 1832.31 & 152.00 & 0.002 & 0.65 \\
\hline
\end{tabular}

$P<0.05, D F=178$ 
Table 2 reveals that neurological assessment has a mean and standard deviation of 51.88 and 17.56 respectively while design of instruction for learners with specific learning disabilities has a mean of 57.71 and standard deviation of 19.97. The $r$ value is $r=0.65$ at degree of freedom of 178 is significant at $p<.05$. The result indicates that neurological assessment has a significant relationship with design of instruction for learners with specific learning disabilities. Therefore, the null hypothesis was rejected. This means that information based on the neurological assessment of a learner determines what content, instructional strategies, materials and method of evaluation to be adopted for a learner with specific learning disabilities.

\section{Discussion of result}

Result for hypothesis one which aimed to find out if there is any relationship between neurological assessment and educational placement options for learners with specific learning disabilities indicates that the variables are related. That is a decision on appropriate placement options such as inclusive classroom, resource room among others are better taken when they are based on valid neurological assessment report on the child. This result is in agreement with Ejue, Orim and Ndifon (2012) whose research on the value of early neurological assessment showed that it has inputs into preventive strategies for the disabilities and most importantly gives directions to educational placement options for the learners. Like Smith (2007), the study holds that it helps in taking decisions to move a child from one placement option to the other. In Dunn's model cascade of services, a child can be transferred from one option if there are evidence from assessment to justify the change. This implies that there is no one option that fits into the condition of all children as each child has a unique need that can be used to determine the placement that will provide the desired intervention services. It is interesting to note that Eno and Orim's (2015) study confirmed findings of this study when their research confirmed that response to instruction (RTI) as model of identification rely on report on this type of assessment to be effective. Association of Learning Disabilities of Canada, ALDC (2012) equally validates the present findings.

Findings from analysis of hypothesis two which sought to find out if the variables, neurological assessment and design of instruction for learners with specific learning disabilities, are related shows that there is significant relationship between them. The result is supported by Bartonova (2014) whose study reveals that instructional content for students with learning disorders in inclusive school is based on professional and comprehensive assessment of children. The author further explained that despite inclusive school culture, specific needs of each child are still the focus of pedagogy. As indicated by this present study, the principle of curriculum policy formulation as defined by Czech Law, Act no: 561/2004 coll as amended gives right to students to 
choose instructional and educational programme based on ability as determined by neurological assessment report and other parameters. The findings of this study are consistent with that of Alfonso and Flauagan (2018) who have earlier identified positive relationship between neurological assessment and content of educational programme for this category of learners.

\section{Conclusion}

This study appreciates the positive relationship that exists between variables investigated and based on the result, stakeholders are enjoined to go beyond ecological assessment to request for neurological assessment for learners with this disability as a basis for proper educational placement decisions and the design as well as content of educational programme. This is informed by the persistent frustration and poor learning outcome associated with the learners despite their above average intellectual ability. In view of this and result of the study it is recommended that:

- Learners with the disability should as matter of policy go through neurological assessment to determine appropriate placement option and nature of instruction to be designed and implemented.

- Parents should be educated on the value of this form of assessment when enrolling their children in school particularly in the seemingly inclusive school era.

- Teachers and support staff should be retrained on how to work with relevant professionals for this assessment.

\section{References}

Alfonso, V., C. \& Flauagan, D., P. (2018). Essentials of specific learning disabilities identification. $2^{\text {nd }}$ Edition. New Jersey: John Wiley \& Son.

Glaeser, B. \& Cote, D. (2012). Neurological basis of learning disabilities: Implications for educational practice. UC Davis Mind Institute. [online]. Retireved from https://www.youtube.com/ watch? $\mathrm{v}=$ gyOIViAl2sU.

Bartoňová, M (2014). Approaches to students with learning disorders in inclusive schools' environment. Brno: Munipress.

Ejue, J., B., Orim, S., O. \& Ndifon, F., O. (2012). Early neurological assessment and prevention of learning disabilities in Nigeria. Akamkpa Journal of Education 2(1), 65-75.

Eno, P., N. \& Orim, S., O. (2015). Models and issues in identification of children with learning disabilities: Implication for professionals in Nigeria. In O. Akinola (Ed). Child care \& special needs education in Nigeria. Abuja: CELDA.

Learning Disabilities Association of Canada. (2012). Prevalence of learning disability. [online]. Retrieved from www.ldac-act.ca/learn-more/ld-basics/prevalence-of Ids.

Lerner, J., W. (1997). Learning disabilities: Diagnosis and teaching strategies. $7^{\text {th }}$ edition. Boston: Houghton Mifflin Company. 
Orim, S., O. (2018). Teachers' utilization of instructional accommodations in teaching learners with dysgraphia in Cross River and Akwa-Ibom state. (Dissertation thesis). Olomouc: Institute of Special Education Studies, UP.

Pierangelo, R. \& Giuliani, G. (2006). Learning disabilities: A practical approach to foundations, assessment, diagnosis and teaching. Boston, MA: Pearson/Allyn and Bacon.

Smith, D., D. (2007). Introduction to special education: Making a difference. $6^{\text {th }}$ edition. Boston: Pearson/Allen and Bacon.

Werner, H. \& Strauss, A. (1990). Causal factor in low performance. American Journal of Mental Deficiency, 45, 213-218.

Wong, B. \& Butler, D., L. (Eds.). (2012). Learning About Learning Disabilities. 4th Edition. San Diego, US: Elsevier Inc.

\section{Contact:}

James Bassey Ejue, Ph.D.

Federal College of Education (FCE), Obudu, Cross River State

Email: info@fceobudu.edu.ng

Orim Samuel Orim Ph.D.

Department of Special Education

University of Calabar

E-mail: samuelorim1@gmail.com

\section{Dr. Orim, Samuel Orim}

I am seasoned special needs education professional with specific learning disabilities as my speciality. I hold a B.Ed, M.Ed and a PhD from University of Calabar, Jos and Palacky University, Olomouc, Czech Republic.

I have published over 30 researched articles in both local and International learned Journals, five book chapters and authored a book titled Introduction to Handwriting Disability: Types,characteristics, theories, diagnosis, technology influence and management. (in press). I have also attended many local and international conferences.

Currently teaching in the Department of Special Education University of Calabar, Nigeria. 